\title{
Al-Turas
}

website : bit.ly/buletinalturas

\section{Kekerabatan Bentuk Kosakata Perabot Dapur dalam Bahasa Arab Sudan dan Suriah}

\author{
Darsita Suparno \\ Jakarta, Indonesia \\ Universitas Islam Negeri Syarif Hidayatullah \\ darsitasuparno@uinjkt.ac.id \\ Ali Qosebaty \\ Jakarta, Indonesia \\ Universitas Islam Negeri Syarif Hidayatullah \\ ali.qosebaty@gmail.com
}

\begin{abstract}
The study is aimed at investigating differences of Amiyah Sudanese and Syrian Arabic lexical forms and meanings in the field of kitchen appliances. It is a study of comparative historical linguistics that uses corpuses of both languages obtained from four Sudanese and Syrian native speaker students who utilize these tools in their everyday modern live. The authors collect the data by themselves applying their own compiled vocabulary list and Swadesh vocabulary list. The findings show that kitchen appliances vocabularies in the Sudanese and Syrian are related to each other. This is evidenced by the the word pairs which (a) are identical or cooccurrence; $(b)$ have a phonemic correspondence or recurrence; and (c) have phonetical similarity with one phoneme difference. In addition, the kitchen appliances usage changes too along with the need in identifying the new words or terms for the new kitchen appliances. It is concluded that the lexical form of Sudanese and Syrian Arabic is systematically compatible, in terms of sound aspects; however sounds of the Sudanese language change in the Syrian vocabulary.
\end{abstract}

Keywords: phonemic; cooccurrence; recurrence; phonetical similarity; kitchen appliances

Doi: $10.15408 /$ bat.v26i1.8781 


\section{Abstrak}

Studi ini bertujuan menyelidiki perbedaan bentuk dan makna dari kosakata bahasa Amiyah Sudan dan bahasa Arab Suriah dalam kosakata dapur dan apa saja bentuk dan makna kata-kata majemuk dalam peralatan dapur ini. Penelitian ini merupakan kajian Linguistik Historis Komparatif dengan menggunakan data dari kedua bahasa tersebut yang diperoleh dari empat mahasiswa penutur jati Sudan dan Suriah yang menggunakan alat masak tersebut setiap hari di era modern. Data dikumpulkan dengan mengacu pada daftar kosakata bahasa Swadesh dan daftar kosakata lainnya. Penelitian ini memperlihatkan bahwa kosakata "peralatan dapur" di Sudan dan Suriah saling terkait. Ini dibuktikan dengan penemuan pasangan kata yang: (a) identik atau terjadi bersamaan (b) memiliki korespondensi fonemik, atau re-aliran fonemik (c) memiliki kesamaan fonetis, dan memiliki satu perbedaan fonem. Penggunaan peralatan dapur juga berubah dengan begitu banyak nama-nama peralatan dapur yang dibutuhkan juga berbeda. Bertumpu pada hasil pembahasan dapat disimpulkan bahwa bentuk leksikal dari Sudan dan Suriah secara sistematis kompatibel, dalam hal aspek suara, ada beberapa suara dari bahasa Sudan yang berubah dalam kosa kata bahasa Syria.

Kata kunci: Fonemik; ko-okurensi; re-kurensi; kemiripan fonetik; peralatan dapur

\section{الملخص}

تهدف هذه الدر اسة إلى البحث في كيفية اختلاف أثكال ومعاني المفردات العربية السودانية و السورية في المفردات المطبخية و أثنكالها ومعانيها المركبة. و حصل الباحث البيانات من أربعة متحدثين سودانيين وسوريين و هم يستخدمون الادوات المطبخية كل يوم في العصر. يتغير استخدام الأدوات

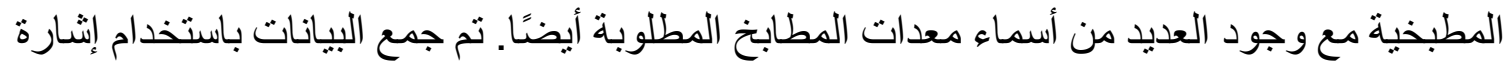
إلى قائمة المفردات Swadesh وقو ائم المفردات الأخرى التي جمعها المؤلف. تستخدم الدراسات

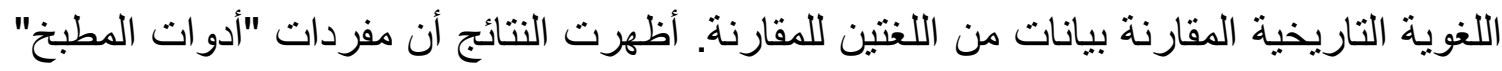
في السودان وسوريا متر ابطة. و بتضح هذا من خلال اكتشاف الكلمات الثنائية التي: (أ) متطابقة

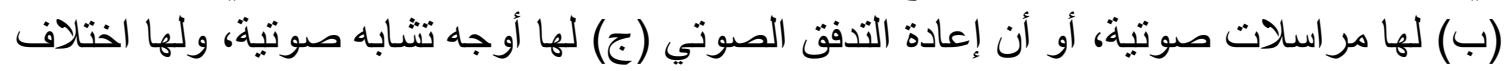

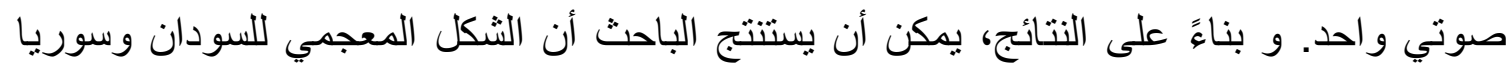
متو افق بثكل منهجي، من حيث الجوانب الصوتية، هناك بعض الأصوات ات من اللغة السودانية التي لئي تتغير في المفردات السريانية.

$$
\text { الكلمات الرئيسية: لفظي; شارك في; إعادة شفاء; نشابه لفظي; أدوات مطبخ }
$$




\section{PENDAHULUAN}

Sejak zaman kuno, bangsa Arab telah melakukan kontak sosial dengan berbagai negara tetangganya seperti bangsa Etiopia, Yunani, Suriah, Nabati, dan lain sebagainya. Dampak dari kontak sosial itu, bahasa Arab menjadi bahasa yang sering digunakan sejak dahulu hingga sekarang (Siemund \& Noemi, 2008, p. 123). Ditinjau dari aspek keragaman bentuk tuturan, bahasa Arab diidentifikasi sebagai bahasa yang jangkauan dan sebaran jumlah penuturnya paling luas. Menurut (Gazali, 2012, p. 150) bahasa Arab memiliki tata-cara berbahasa yang dipilah menjadi berbahasa baku yang disebut dengan Standard Arabic (SA). Dijelaskan lebih lanjut bahwa bahasa baku dalam bahasa Arab yang dikenal dengan istilah bahasa arab klasik ( التراثية العربية اللغة (dikenal juga dengan terminology the Classical Arabic (CA), secara historis bahasa ini telah dipakai oleh penutur jati bahasa Arab sejak abad ke tujuh hingga sembilan Masehi, bahasa-bahasa itu masih terfokus kepada Kitab Alquran dan naskah-naskah priode awal Islam; kedua Bahasa Arab baku modern (الحديثة المعيارية العربية اللغة (atau Modern Standard Arabic (MSA), secara historis merupakan hasil dinamika masyarakat penutur jati bahasa Arab yang terus melaukan pengembangan di bidang bahasa khususnya dari bahasa Arab klasik yang mengalami perubahan dalam aspek pemakaian bahasa dalam peribadatan, yang dipakai pada saat ini sebagai bahasa formal (Gazali, 2012, pp. 152-153).

Bahasa Arab pada era industri 4.0 ditinjau dari aspek pemakaian dan penyebarluasan pemakaian ditandai dengan digitalisasi dan otomasi. Bahasa ini sekarang menduduki beberapa peran penting, antara lain yakni: a) bahasa Arab merupakan salah satu bahasa lingua franca yang dipakai secara luas atau sudah menjadi bahasa pengantar di Perserikatan Bangsa-Bangsa untuk kebutuhan konumikasi internasional; b) penutur bahasa jati bahasa Arab diperkirakan mencapai 250 juta jiwa yang tersebar di 22 negara; c) bahasa Arab merupakan bahasa Al-Quran, kitab suci umat Islam yang dipergunakan secara luas di seluruh negara muslim; d) bahasa Arab juga diidentifikasi sebagai bahasa tertua di dunia karena kosakata bahasa ini mudah ditelusuri akar katanya, penulusuran secara etimologi berdampak diketahuinya bahwa banyak kosakata bahasa ini diindikasikan sebagai cikal bakal banyak kosakata bahasa-bahasa di dunia.

Bahasa Arab adalah bahasa yang digunakan oleh sebagian besar penduduk di kawasan Timur Tengah dan Afrika Utara, (Setiadi, 2011, p. 135). Bahasa Arab berkedudukan sebagai bahasa resmi kenegaraan di 17 wilayah seperti di negara: 1) Aljazair, 2) Mesir, 3) Irak, 4) Yordania, 5) Kuwait, 6) Lebanon, 7) Libya, 8) Mauritania, 9) Maroko, 10) Oman, 11) Arab Saudi, 12) Sudan, 13) Suriah, 14) Tunisia, 15) Uni Emirat Arab, 16) Sahara Barat, dan 17) Yaman. Selain itu, kini bahasa Arab memiliki peran dan kedudukan sebagai bahasa resmi Perserikatan Bangsa-Bangsa, di sisi beberapa bahasa resmi lainnya seperti Cina, Inggris, Rusia, dan Spanyol. Bahasa Arab memiliki tiga ragam yaitu: a) Klasik atau yang terdapat di dalam Alquran, b) Standar Formal atau Modern, c) bahasa sehari-hari (amiyah; colloquial; spoken language).

Ditinjau dari sudut rumpun, bahasa Arab merupakan rumpun dari bahasa SemitoHamit atau Afro-Asiatik. Rumpun bahasa ini terdiri dari dua sub rumpun yaitu: a) sub rumpun Hamit mencakupi: bahasa Koptis, Berber, Kushit dan Chad; b) sub rumpun bahasa Semit terdiri dari bahasa Arab, Etiopik dan Ibrani, (Keraf, 1996, p. 25). Bahasa Arab dikenal dengan bahasa Arab Klasik, Standar Modern Arab dan kolokial. Perbedaan antara bahasa Arab klasik, bahasa Arab standar modern, dan kolokial atau Amiyah atau sering disebut berbagai ragam lisan bahasa Arab terletak pada pengucapannya. Setiap wilayah pemakai bahasa Arab amiyah memiliki penciri (features) bunyi yang khas, yang tidak sama dari satu wilayah kepada wilayah lain. ragam penciri kha situ terjadi karena 
bahasa selalu berubah. (Owen, 2015, p. 11; Trask, 2010, p. 1). Berangkat dari perbedaan yang terdapat pada bahasa lisan (colloquial) inilah dapat dilakukan klasifikasi ragam bahasa lisan itu. Calvani (2003), misalnya menjelaskan bahwa bahasa Arab ragam lisan dapat dibedakan antara lain bahasa Arab dialek Mesir, Sudan, Arab Saudi, Afrika barat laut, Suriah (termasuk Lebanon, Jordania) dan Irak, (Calvani, 2003, p. 8). Mengapa bahasa Arab itu memiliki penyebaran yang luas? Ditinjau dari aspek historis, bahasa Arab sudah mengalami penyebarannya yang sangat luas dan pesat pada saat para tokoh cendekiawan Islam berkuasa dan menguasai berbagai negara Timur Tengah. Terkait dengan keadaaan itu bahasa Arab menjadi alat komunikasi yang memegang peran utama sejak dulu hingga kini. Perkembangan yang pesat dan kekerapan kontak sosial dalam berbagai aspek kehidupan, seperti (perniagaan, politik, pendidikan, kesusasteraan) antar masyarakat penutur berbahasa Arab dengan masyarakat lain berdampak kepada pembentukan kosa kata baru dalam berbagai bahasa seperti dalam bahasa Barbar, Kurdi, Parsi, Swahili, Hindu, Turki, Tunisia, Sudan, Suriah, Mesir dan sebagainya. Ditinjau secara geografis, letak masyarakat bahasa Sudan dan Suriah dapat dilihat dalam gambar 1 (World Map: Political, 2008).

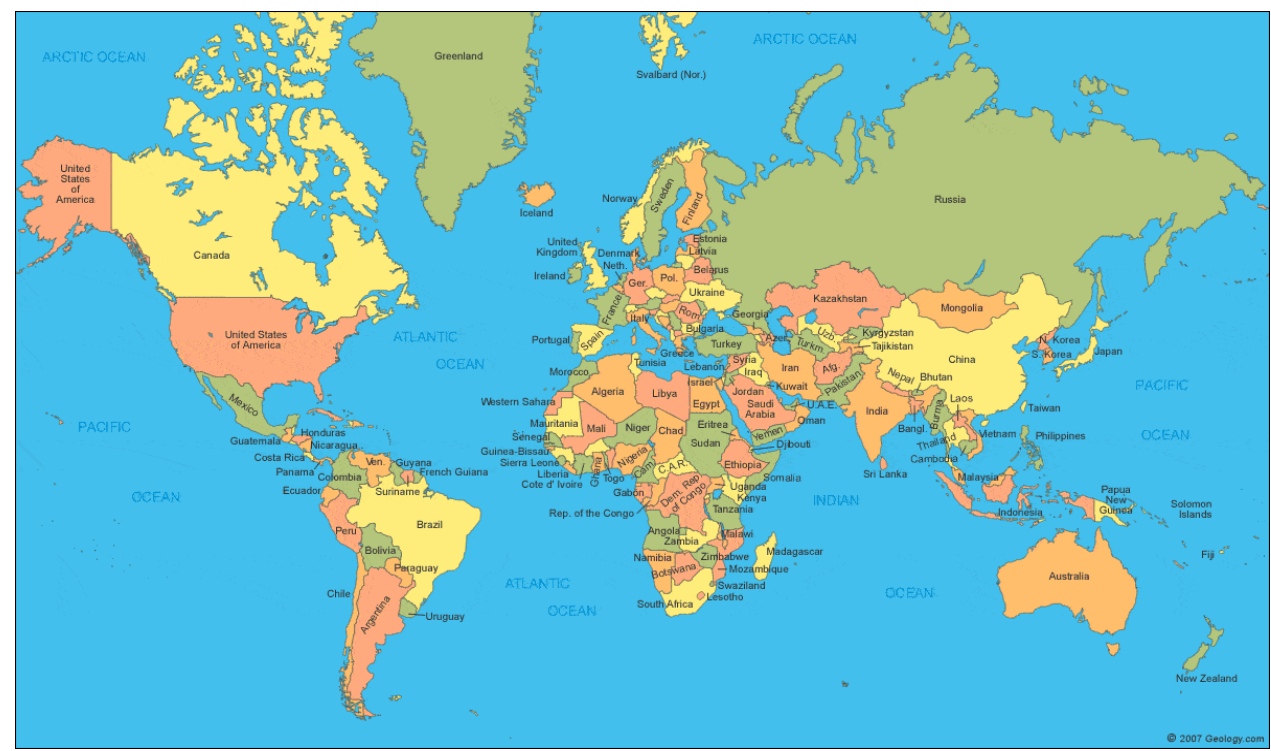

Gambar 1. Peta Wilayah Sudan dan Suriah

Peta di atas menunjukkan bahwa letak wilayah yang berdekatan antar ke dua negara itu memungkinkan terjadinya kekerapan interaksi sosial yang menggunakan bahasa lisan dalam berbagai ranah. Calvani (2003) menjelaskan bahwa penutur bahasa Sudan dan Suriah berhubungan secara fisik melalui komunikasi secara lisan (Calvani, 2003, p. 8). Persentuhan fisik dalam berbagai kegiatan sehari-hari dapat berdampak kepada terbentuknya kesamaan bahasa terutama dalam aspek kosa kata.

Contoh lain dalam kontak sosial misalnya orang Sudan dan Suriah memang sudah melakukan hubungan dalam bidang perdagangan sudah sejak lama, bahan yang diperdagangkan antara lain: buah-buahan, sayuran, gandum, jagung, selai, minyak sayur, (Mahmoud \& Rosiny, 2015, p. 5). Kontak sosial dalam bentuk organisasi, dapat disaksikan umpamanya pada Gerakan Tentara Islam (GTI) atau Legium Islam Internasional. Organisasi ini memiliki anggota berjumlah 2.830 orang anggota yang terdiri dari 177 orang Aljazair, 594 orang Mesir, 410 orang orang Yordania, 53 orang Maroko, 32 orang Palestina, 162 orang Suriah, 111 orang Sudan, 63 orang Tunisia, 291 
orang Yaman, 255 orang Irak, dan lain-lain berasal dari negara-negara Teluk (Djelantik, 2016, p. 42). Fakta di atas mengindikasikan bahwa penutur jati bahasa Arab Sudan dan bahasa Suria berhubungan sosial melalui komunikasi lisan. Situasi itu juga menunjukkan ada persentuhan sosial yang hubungannya bersifat timbal balik antara Sudan dan Suriah. Di sisi yang lain bahasa Amiyah Sudan dan Suriah berasal dari satu rumpun yang sama, yaitu rumpun Semito Hamit atau Afro-Asiatik sehingga kedua bahasa itu berkerabat karena diturunkan secara genetik dari induk bahasa yang sama.

Pertanyaan dasar yang muncul adalah jika sebuah bahasa diturunkan dari satu induk yang sama apa perbedaan dan kesamaan di antara dua bahasa tersebut. Bertumpu dari pertanyaan dasar itu, penelitian ini akan menjelakan bentuk dan makna kosakata bahasa Arab Amiyah Sudan dan Suriah dalam kosakata peralatan dapur, dan bentuk serta makna kata majemuk bahasa Arab Amiyah Sudan dan Suriah dalam peralatan dapur. Hasil penelitian ini diharapkan dapat membantu melakukan inventarisasi bahasa Arab Amiyah Suriah yang sekarang ini dilanda konflik dan peperangan yang tak kunjung selesai. Di sisi lain, tulisan ini dapat bermanfaat untuk mengetahui ragam bahasa Arab Amiyah khususnya Sudan dan Suriah dalam ranah peralatan dapur. Hubungan kekerabatan bahasa Amiyah Suriah dan Sudan dapat dilihat dari kesamaan kosa kata dan maknanya, (Calvani, 2003, p. 8).

Para ahli yang menulis tentang Suriah dan Sudan sudah banyak dilakukan para ahli. Taha A Taha (2012) dengan judul The Influence of Dongolawi Nubian on Sudan Arabic meneliti kekerabatan bahasa. Kemiripan bunyi dan aspek pinjaman dipakai untuk melakukan penetapan kata kerabat. Tujuan yang hendak dicapai adalah mendeskripsikan dampak bahasa Dongolawi Nubian terhadap bahasa Arab di Sudan. Bahasa Arab yang digunakan di Sudan banyak meminjam kosa kata bahasa Dongolawi Nubian khususnya pada ranah pertanian, irigasi, peralatan terkait dengan bidang pertanian (Taha, 2012, p. 22)

Tulisan para ahli itu tentu dapat membantu terinventarisasinya bahasa Arab Amiyah Suriah yang sekarang ini dilanda konflik dan peperangan yang tak kunjung selesai. Namun, kajian yang membahas ragam bahasa Arab Amiyah khususnya Sudan dan Suriah dalam ranah peralatan dapur, belum dilakukan sejaup penelusuran kepustakaan yang dilakukan penulis ini. Terkait dengan situasi itu, kajian ini focus kepada hubungan kekerabatan bahasa Amiyah Suriah dan Sudan dapat dilihat dari kesamaan kosa kata dan maknanya, (Calvani, 2003, p. 8). Penelitian kekerabatan bahasa pernah dilakukan oleh Taha A. Taha (2012) dengan judul The Influence of Dongolawi Nubian on Sudan Arabic. Kemiripan bunyi dan aspek pinjaman dipakai untuk melakukan penetapan kata kerabat. Tujuan yang hendak dicapai adalah mendeskripsikan dampak bahasa Dongolawi Nubian terhadap bahasa Arab di Sudan. Bahasa Arab yang digunakan di Sudan banyak meminjam kosa kata bahasa Dongolawi Nubian khususnya pada ranah pertanian, irigasi, peralatan terkait dengan bidang pertanian (Taha, 2012, p. 22).

Penelitian kekerabatan bahasa Jawa dan Sunda terkait kosakata alat dapur pernah dilakukan oleh Emma Maemunah (2017) dengan judul "Kekerabatan bentuk dan makna kosakata peralatan dapur dalam bahasa Sunda dan Jawa". Paradigma yang digunakan untuk melihat objek itu adalah linguistik historis komparatif dengan dasar perbandingan mecakupi beberapa aspek antara lain: kemiripan fonetis; kemiripan semantis, yang dilihat dari tiga faktor yaitu warisan langsung, faktor kebetulan dan faktor peminjaman. Teknik leksikostatistik digunakan untuk mendapatkan data. Untuk penetapan kata kerabat dipakai: a) aspek kemiripan fonetis, b) perubahan fonetis, dan c) korespondensi fonemis, (Keraf, 1996, p. 31). 
Penelitian yang dilakukan Owens (2013) menjelaskan bahwa morfem yang banyak dibahas dalam linguistik historis Semit adalah sufiks /-n/. Owen mengkaji bahasa Arab klasik yang dibandingkan dengan bahasa Akkadia (lišānum akkadītum) merujuk kepada sebuah bahasa Semitik (bagian dari keluarga bahasa Afro-Asia yang lebih besar) yang digunakan di Mesopotamia kuno, khususnya oleh bangsa Asyur dan Babilonia. Hasil penelitiannya menunjukkan bahwa dalam bahasa bahasa ini banyak terdapat gejala bahasa yang disebut refleks [V - n - objek] atau bentuk akhiran verbal proto-Semit. Selain itu, penelitian ini menunjukkan konstruksi frase berbentuk [kata ganti objek / presentatif + objek]. Owens berpendapat rekonstruksi umum morfem dalam konteks Semit Barat memiliki bentuk sufiks /-n/ bentuk ini sangat penting untuk konseptualisasi linguistik sejarah Arab dan Semit. Morfem yang banyak dibahas dalam linguistik historis Semit adalah sufiks /-n/ (Owens, 2013, pp. 217-219).

Penelitian ini berbeda dengan penelitian yang dilakukan oleh Taha (2012), Owens (2013) dan Emma (2017). Penelitian ini enggunakan metode simak libat cakap dengan teknik kuesioner dengan sudut pandang linguistik historis komparatif. Untuk penetapan kata kerabat digunakan perangkat korespondensi fonemis dengan tiga indikator, yaitu: a) rekurensi fonemis (phonemic recurrence); b) ko-okurensi (co-occurrence); c) analogi (analogy), demikian cara penetapan kata kerabat yang dikemukakan oleh (Keraf, 1996, p. 31).

Kajian ini menggunakan linguistik bandingan historis sebagai landasan teoretis, sebuah teori yang merujuk kepada suatu cabang ilmu bahasa yang mempersoalkan bahasa dan perubahan-perubahan unsurnya dalam waktu tertentu (Keraf, 1996, p. 36; Trask, 2010, p. 11). Pengenalan atas dua bahasa atau lebih diarahkan untuk mengetahui apakah ada kesamaan-kesamaan tertentu atau tidak dalam bahasa-bahasa yang diperbandingkan. Kesamaan-kesamaan dan perbedaan-perbedaan antara dua bahasa atau lebih yang diperbandingkan itu untuk mengetahui pakan unsur-unsur yang sama itu merupakan bukti bahwa dalam jaman dahulu bahasa-bahasa tersebut merupakan suatu bahasa tunggal. Tujuan Linguistik Bandingan Historis menurut Keraf (1996) adalah mempersoalkan bahasa-bahasa yang serumpun dengan mengadakan perbandingan mengenai unsur-unsur yang memperlihatkan kekerabatannya (Crowley \& Bowern, 2019, p. 35; Keraf, 1996, pp. 30-36; Siemund \& Noemi, 2008, pp. 3-22). Bidang-bidang yang dipergunakan untuk mengadakan perbandingan semacam itu adalah fonologi, dan morfologi, (Muysken, 2019, pp. 50-55). Tujuan berikutnya adalah merekonstruksi bahasa-bahasa yang ada dewasa ini kepada bahasa purba (bahasa-bahasa proto) atau bahasa-bahasa yang menurunkan bahasa-bahasa kontemporer, mengelompokkan bahasa-bahasa yang termasuk dalam suatu rumpun Bahasa, dan menemukan pusat-pusat penyebarannya bahasa-bahasa proto dari bahasa-bahasa kerabat serta menentukan gerak migrasi yang pernah terjadi.

Bila wilayah bahasa-bahasa kerabat sudah diketahui dan sudah berhasil pula ditentukan negeri asal dari bahasa-bahasa kerabat itu, maka dapat direkonstruksi gerak perpindahan (migrasi) dari negeri asal ke daerah-daerah yang sekarang diduduki oleh penutur bahasa-bahasa kerabat tersebut. Bidang Perbandingan dalam studi linguistik komparatif merupakan aspek bahasa yang paling cocok untuk dijadikan bahan studi perbandingan adalah bentuk yang memperlihatkan pula kesamaan-kesamaan makna atau semantik. Gorys (1996) menjelaskan bahwa tiap bahasa di dunia memiliki ciri-ciri kesemestaan (universal) tertentu (Keraf, 1996, p. 32). Emma (2017) menjelaskan bahwa kesemestaan bahasa mencakup dimensi kesamaan dalam bentuk dan makna, fonem dan morfem, dan kelas kata. 


\section{METODE}

Metode analisis yang digunakan adalah sinkomparatif dan diakomparatif. Metode sinkomparatif diterapkan terlebih dahulu dengan maksud untuk menganalisis data bahasa-bahasa serumpun secara sinkronis dalam hal ini bahasa Arab dialek Sudan dianggap serumpun dengan bahasa Arab dialek Suriah. Metode ini digunakan berdasarkan kenyataan bahwa penelitian perbandingan bahasa selalu diawali dengan pendekatan sinkronis. Untuk deskripsi fonem digunakan metode analisis sinkomparatif untuk fokus analisis fonem dan penemuan aspek perubahan fonologis secara deskriptif (La Ino, 2015, p. 353). Analisis ini dilakukan untuk mencari tahu gejala perbedaan fonem, alofon beserta variannya, dan hubungan setiap fonem pada masing-masing sistem fonologi bahasa Sudan dan Suriah.

Secara metodologi ada tiga tataran, sebagaimana digambarkan dalam gambar 1 sebagai berikut:

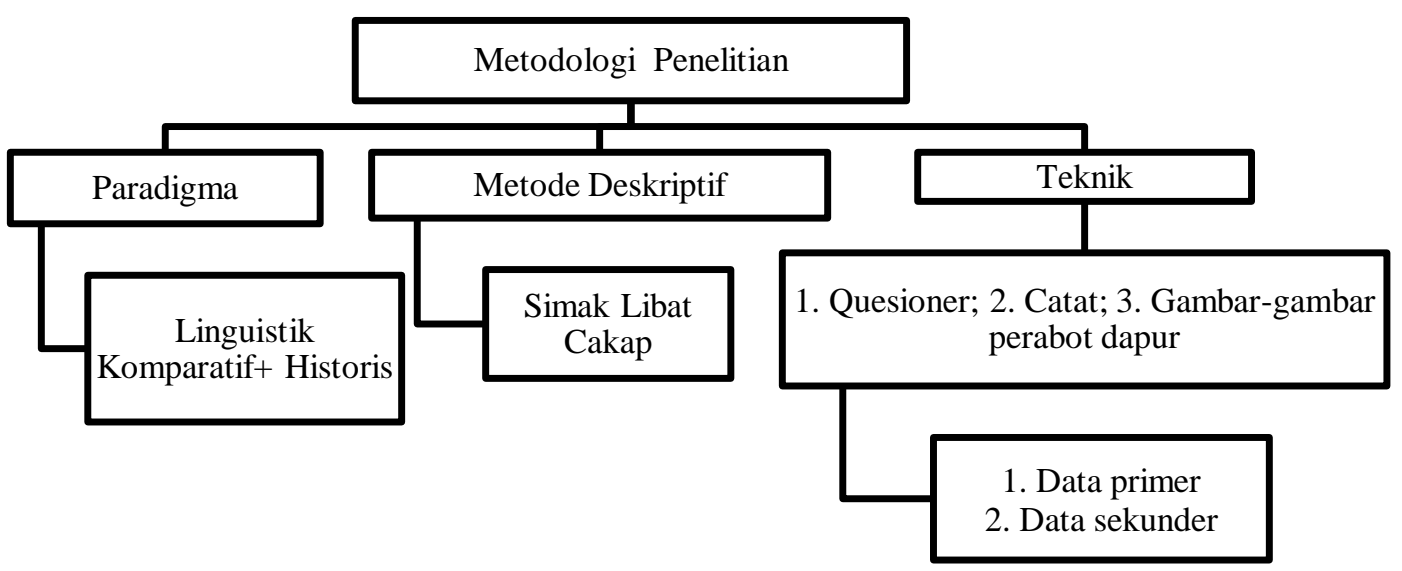

Gambar 2. Skema Metodologi Penelitian

Gambar 2 di atas dijadikan panduan pelaksanaan proses penelitian ini. Linguistik historis komparatif merupakan sebuah paradigma berpikir dilengkapi dengan metode deskriptif simak libat cakap (Sudaryanto, 2015, p. 15). Metode penelitian ini dikategori sebagai deskriptif sinkronis kualitatif. Langkah-langkah data dihimpun dengan cara membuat daftar kosa-kata alat dapur dalam bahasa Inggris sebagai daftar kuesioner, analisis dan paparan hasil penyajian. Sebagaimana dipaparkan oleh (Sudaryanto, 2015, p. 5). Metode simak memakai teknik sadap dan catat digunakan untuk proses mengumpulkan data. Metode simak diarahkan untuk mengambil data dengan cara menyadap atau menyimak pemakaian bahasa. Sudaryanto mengusulkan terminologi, menyimpak memiliki peran penting dalam meneliti data bahasa yang merujuk kepada pemakaian bahasa secara lisan, bahasa yang terdapat dilama nasakah kuno, teks narasi maupun bahasa-bahasa yang terdapat di dalam media massa dan lain sebagainya, (Sudaryanto, 2015, pp. 5-6). Selanjutnya, metode kartu data atau kotak dalam bentuk power point dipakai untuk mencatat data dalam bentuk yang tertata dan diberi penomoran. Data yang sudah terkumpul itu dianalisis menggunakan metode padan intralingual. Metode padan intralingual merujuk tata-cara analisis bahasa dengan mengamati satuan bahasa lalu menghubung-bandingkan unsur-unsur yang bersifat lingual itu, baik yang terdapat dalam satu bahasa maupun dalam beberapa bahasa yang berbeda, demikian 
(Mahsun, 2012, pp. 87-117). Metode perbandingan dengan menggunakan korespondensi sistematis mengamati perbedaan secara fonetis setiap kosa kata yang diperbandingkan (Miller, 2015, pp. 281-284; Yule, 2010, pp. 227-228).

Teknik merujuk kepada alat yang digunakan yaitu berupa: sekumpulan pertanyaan atau kuesioner berisi daftar kosakata peralatan dapur yang dilengkapi dengan gambar untuk memudahkan terjadinya persamaan objek yang dituju antara peneliti dan informan. Daftar pertanyaan itu dipilah dalam empat kolom terdiri dari kolom gloss berbahasa Inggris, kolom gambar, kolom bahasa Sudan dan Suriah. Kosakata yang dicari adalah peralatan dapur; yang dilihat dari aspek bentuk dan makna.

Data yang digunakan dalam penelitian ini dikelompokkan dalam 2 jenis: primer dan sekunder. Data primer berupa daftar kosakata yang berfokus pada medan makna 'peralatan dapur,' sementara data sekunder berupa hasil wawancara dengan penutur jati bahasa Arab Amiyah Suriah dan Sudan sebagai informan kunci. Data dikumpulkan dengan teknik catat dengan menggunakan daftar kosakata Swadesh (Swadesh word list) peralatan dapur ditambah kosakata peralatan dapur lainnya dari berbagai sumber untuk melengkapi kosakata yang tidak terdapat dalam daftar kosakata Swadesh. Setelah data terkumpul wawancara terhadap informan dilakukan kembali sebagai bentuk triangulasi data.

Alat-alat ucap para informan yang menjadi fokus perhatian peneliti dalam memahami bunyi bahasa Arab dialek Sudan dan Suriah ini antara lain: 1. bibir (Lips/ asy-Syafah) 2 . gigi atas gigi bawah (Teeth/al-Asnan) 3. pangkal lidah atau gusi (Teeth-riclge/Usulul asnan), 4. langit-langit tengah atau langit-langit keras (Hard Palate/Wasalul Hanak, alHanakul Solbu) 5. langit-langit dalam/Langit-langit lunak (soft palate/ Aqsa al-Hanak, alHakullainu) 6. Tekak (Uvula/al-Luhat) 7. Ujung lidah (Blade of Tonge/Torful-lisan) 8. tengah lidah (central of tonge/wasatul-lisan) 9. lidah belakang (back of tonge/mu'akharullisan) 10. anak lidah (epiglottis/lisanul muznari) 11. tenggorokan (pharynx/al-halaq) 12. pita suara (vocal cords/al-witrani as-sautiyani) 13. posisi glotal (position of larynx/mantiqatul hawaiyah) 14. pipa suara (windpipe/ al-qasbatul hawaiyah) 15. pangkal nasal (faragatul anafi) 16. Aliran udara ke hidung atau nasal (fathatul anaf). Alat-alat ucap para informan harus lengkap dan dalam keadaan baik, agar bunyi bahasa yang dihasilkan dapat didengar oleh peneliti ini dengan baik pula. Penelitian fonologi bahasa Arab yang memperhatikan alat ucap manusia juga dilakukan oleh (Mu'izzuddin, n.d., pp. 73-74). Analisis data dilakukan dengan melalukan prosess pendefinisian dan pengelompokkan (classification). Pada tataran pendefinisian, data dalam kosakata peralatan dapur ini diberi definisi sesuai apa yang dijelaskan oleh informan. Data yang telah didefinisikan, kemudian diklasifikasikan dan dikelompokkan sesuai dengan pembahasan bentuk dan makna yang diamati.

\section{TEMUAN DAN PEMBAHASAN}

Analisis data diarahkan kepada penetapan kata kerabat dengan memakai metode kemiripan bentuk dan makna, sebagaimana dikemukakan oleh (Keraf, 1996, pp. 128129). Kata-kata yang sama dalam sebuah pasangan akan dinyatakan sebagai kata kerabat, sedangkan yang berbeda dinyatakan sebagai kata non kerabat. Sebuah pasangan kata akan dinyatakan sebagai kata kerabat bila memenuhi salah satu ketentuan berikut: a) Pasangan itu identik. Pasangan kata yang identik adalah pasangan kata yang semua fonemnya sama betul; b) Pasangan itu memiliki korespondensi fonemis. Bila perubahan fonemis antara dua bahasa itu terjadi secara timbal balik dan teratur, serta tinggi frekuensinya, maka bentuk yang berimbang antara kedua bahasa itu dianggap berkerabat. Dalam hubungan 
ini okurensi fonem-fonem yang menunjukkan korespondensi itu dapat mengikutsertakan gejala-gejala kebahasaan yang lain yang disebut ko-okurensi; c) kemiripan secara fonetis merujuk kepada pasangan kata yang memiliki ciri-ciri fonetis yang cukup serupa sehingga kemiripan itu dianggap sebagai variasi bunyi atau alofon; d) satu fonem berbeda merujuk kepada apabila dalam satu pasangan kata t erdapat perbedaan satu fonem, tetapi dapat dijelaskan bahwa perbedaan itu terjadi karena pengaruh lingkungan yang dimasukinya, sedangkan dalam bahasa lain pengaruh itu tidak mengubah fonemnya, maka pasangan itu dapat ditetapkan sebagai kata kerabat, asal segmennya cukup panjang. Kedua bahasa yang dibandingkan yaitu Sudan dan Suriah dibandingkan dengan konsep dasar (gloss), yaitu bahasa Inggris. Berikut ini beberapa contoh kosakata bahasa Arab Amiyah Sudan dan Suriah terkait dengan perabot dapur dengan kategori berikut.

\section{Pasangan itu dentik}

Berikut ini pasangan kata yang identik adalah pasangan kata yang semua fonemnya sama betul. Berikut ini data pasangan-pasangan kata yang bentuk, bunyi, dan makna yang identik pada tabel 1.

Tabel 1. Kosakata Perabot Dapur

\begin{tabular}{|c|c|c|c|c|c|}
\hline No & Makna & $\begin{array}{l}\text { Kosakata } \\
\text { Sudan }\end{array}$ & $\begin{array}{l}\text { IPA Pronunciation/ } \\
\text { transliterasi fonetik }\end{array}$ & $\begin{array}{l}\text { Kosakata } \\
\text { Suriah }\end{array}$ & $\begin{array}{l}\text { IPA Pronunciation/ } \\
\text { transliterasi fonetik }\end{array}$ \\
\hline 1. & 'garpu' & شَوْكَ & /Jaukah/ & شوكه & /fo:keh/ \\
\hline 2. & 'mesin cuci piring' & غسالة صحون & /gas:alah shuhun/ & غسالة صحون & /ghassaalet shehuun/ \\
\hline 3. & 'alat bakar' & شَوَّاَيَه & /syawwaayah/ & شوّايه & /syawwaayeh/ \\
\hline 4. & 'nampan' & صِيْنِيَه & /shiniyyah/ & صينيه & /shiiniyyeh/ \\
\hline 5. & 'mesin cuci & غَسَّالَه & /gassaalah/ & غساله & /ghassaaleh/ \\
\hline 6. & 'tampah' & غُرْبَالْ & /ghurbaal/ & 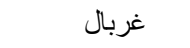 & /gherbaal/ \\
\hline 7. & 'meja makan' & صُفْرَه & /shufrah/ & صُفرَره & /shufrah/ \\
\hline 8. & 'pisau' & سِكِيْنْ & /sikkiin/ & سِكِيْنْ & /sikkiin/ \\
\hline 9. & 'parut' & بَبََّّارَه & 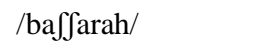 & بَشََّّارَه & 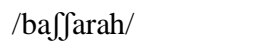 \\
\hline
\end{tabular}

Data kosakata pada Tabel 1 menunjukkan beberapa pasangan identik memiliki perbedaan dalam variasi pengucapannya. Kosakata Sudan شَوَكَه diucapkan / Jaukah/ / Jaukeh/ dalam Suriah. Pada pasangan ini terdapat perubahan dari bunyi bunyi /a/ ke /e/; serta /u/ ke /e/ pada kosakata غَرْبَ /ghurbaal/ dan /gherbaal/. Data lain menunjukkan gejala yang sama terdapat pada kosa kata Sudan / غسالة صحون / diucapkan /gas:alah shuhun/ /ghassaalet shehuun/ bermakna alata cuci piring. Data table 1 menunjukkan banyak morfem dan leksem atau kosakata dalam bahasa Arab seperti Sudan dan Suria yang bentuknya mirip atau bahkan sama namun dari aspek fonetik berbeda, walaupun fungsi dan maknanya sama. Contoh lain bahasa Arab yang memiliki pasangan identik, Amiyah Sudan memiliki kosakata [ هواء] 'angin'; [ كلب ] 'anjing'; [نان] 'asap'. Demikian pula, bahasa Arab Amiyah Suriah memiliki kosa kata [ هواء ] 'angin'; [ هلب] 'anjing'; [ [نان 'asap'. Contoh lain lagi dapat dilihat pada kesamaan kosakata sifat. Kosakata pada Tabel 1 menunjukkan beberapa pasangan identik memiliki perbedaan dalam variasi pengucapannya. Kosakata Sudan شَوْكَه diucapkan / faukah/ / Jaukeh/ dalam Suriah. Pada pasangan ini terdapat perbedaan bunyi /a/ dan /e/; serta /u/ dan /e/ pada kosakata غُرْبَالْ /ghurbaal/ dan /gherbaal/.

Data tertera pada table 1 menunjukkan banyak morfem dan leksem atau kosakata dalam bahasa Arab seperti Sudan dan Suria yang bentuknya mirip atau bahkan sama 
namun dari aspek fonetik berbeda, walaupun fungsi dan maknanya sama. Contoh lain bahasa Arab yang memiliki pasangan identik, Amiyah Sudan memiliki kosakata [هو اء 'angin'; [ كلب] 'anjing'; [ دخان] 'asap'. Demikian pula, bahasa Arab Amiyah Suriah memiliki kosa kata [هواء ] 'angin'; [ كلب ] 'anjing'; [ دخان] 'asap'. Contoh lain lagi dapat dilihat pada kesamaan kosakata sifat yang terkait dengan perlatan dapur yang sering dipakai oleh masyarakat Sudan dan Suriah dapat dilihat pada tabel 2.

Tabel 2. Kosakata Ajektiva

\begin{tabular}{|c|c|c|c|c|c|}
\hline No. & Makna & $\begin{array}{l}\text { Kosakata } \\
\text { Sudan }\end{array}$ & $\begin{array}{l}\text { IPA Pronunciation/ } \\
\text { transliterasi fonetik }\end{array}$ & $\begin{array}{l}\text { Kosakata } \\
\text { Suria }\end{array}$ & $\begin{array}{l}\text { IPA Pronunciation/ } \\
\text { transliterasi fonetik }\end{array}$ \\
\hline 1. & 'banyak' & كتير & /katiir/ & كَيْيَزْ & /ketiir/ \\
\hline 2. & 'baru' & جديد & /jadiid/ & جَدِيْدْ & /jadiid/ \\
\hline 3. & 'basah' & مبلول & /mabluul/ & مَبْلُوْْن & /mabluul/ \\
\hline 4. & 'betul' & صح & /shoh/ & صَحٌْ & /shohh/ \\
\hline 5. & 'besar' & كبير & /kabiir/ & كَبْيز & /kebiir/ \\
\hline
\end{tabular}

Sumber Data: No 18, 20, 21, 25, dan 32 dalam Darsita, Ali Qosibati, dan Syahril Arnas (2017)

Data pada tabel 2 menunjukkan kosakata-kosa kata tersebut terjadi perubahan fonem, misalnya fonem /a/ menjadi /e/; /h/ menjadi /h:/. Data yang tertera di atas menunjukkan bahwa kedua bahasa itu memiliki bahasa proto yang sama. Keadaan ini sesuai dengan pernyataan Keraf (1996: 35), (Trask, 2010, pp. 1-5) yang menjelaskan bahwa kemiripan fonetis dan semantik antara dua atau beberapa bahasa terjadi karena beberapa factor.

\section{Warisan Bentuk Kerabat (Cognate)}

Terdapat Warisan langsung dari suatu bahasa proto yang sama yang dinamakan bentuk kerabat (cognate) sebagaimana tabel 3.

Tabel 3. Kosakata Verba Bahasa

\begin{tabular}{|c|c|c|c|c|c|}
\hline No. & Makna & $\begin{array}{l}\text { Kosakata } \\
\text { Sudan }\end{array}$ & $\begin{array}{l}\text { IPA Pronunciation/ } \\
\text { transliterasi fonetik }\end{array}$ & $\begin{array}{l}\text { Kosakata } \\
\text { Suriah }\end{array}$ & $\begin{array}{l}\text { IPA Pronunciation/ } \\
\text { transliterasi fonetik }\end{array}$ \\
\hline 1. & 'berenang' & سباحة & /sabaah/ & سِبَاحَهْ & /siibahah/ \\
\hline 2. & 'berjalan’ & 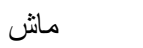 & /maasyi/ & مَنَشْيْ & /masyi/ \\
\hline 3. & 'mencium' & قبلة قبلة & /qublah/ & لَبوسنْ & /boos/ \\
\hline 4. & 'datang' & جاي & /jay/ & إِجَا & /ijaa/ \\
\hline 5. & 'mendengar' & اسمع & /isma?/ & سَمْنْ & /same?/ \\
\hline
\end{tabular}

Sumber Data: No 29, 31, 46, 52, dan 57 dalam Darsita, Ali Qosibati, dan Syahril Arnas (2017)

Data pada table 3 diidentifikasi sebagai kosakata yang kognate. Kognate merujuk kepada kosakata dengan bunyi yang sama atau hamper mirip dalam sebuah kata, maka bahasa-bahasa yang dibandingkan itu diasumsikan mereka berasal dari satu bahasa proto atau satu keturunan leluhur yang sama demikian (Miller, 2015, p. 256). Data pada table 3 bukan merupakan kosakata yang terkait dengan perlatan dapur, tetapi cara melihat kosakata verba pun menunjukkan bahasa Sudan dan Suriah berasal dari satu keturunan bahasa yang sama. Perbedaan bunyi yang terjadi pengalaman, kontak sosial, idiolek perorangan, perdagangan, Pendidikan, politik atau factor factor non kebahasaan lain, seperti keragaman status atau peran sosial.

\section{Faktor Kebetulan (By Chance)}

Berikut kosakata dapur bahasa Arab Amiyah Sudan dan Suriah yang memiliki kekerabatan karena faktor kebetulan pada tabel 4. 
Tabel 4. Kosakata Perabot Dapur Bahasa Arab Amiyah Sudan dan Suriah

\begin{tabular}{|c|c|c|c|c|c|}
\hline No. & Makna & Sudan word & $\begin{array}{l}\text { IPA Pronunciation/ } \\
\text { transliterasi fonetik }\end{array}$ & Suriah word & $\begin{array}{l}\text { IPA Pronunciation/ } \\
\text { transliterasi fonetik }\end{array}$ \\
\hline 1. & 'ceret' dan 'kulkas & بَرَّاد اذ & /barraad/ & برّاد & /barraad/ \\
\hline 2. & $\begin{array}{l}\text { 'penggorengan' dan } \\
\text { 'pengaduk kopi' }\end{array}$ & غَلَّاَيَهَه & /ghallaayah/ & غَلَّيه & /ghallaayeh/ \\
\hline
\end{tabular}

Sumber Data: No 8, 22 dan 29, 39 dalam Darsita, Ali Qosibati, dan Syahril Arnas (2018)

Sumber Gambar: http://www.goethe-verlag.com (Learn English and other languages online for free, n.d.)

Kata bahasa Arab Sudan براد barād, misalnya, berarti 'teko', sedangkan dalam bahasa Arab Syria diterjemahkan sebagai 'lemari es'. Akar kata [barād] adalah $\boldsymbol{b}$ (a) $\boldsymbol{r}$ (a) $\boldsymbol{d}$ (a), bermakna 'menjadi dingin'. Jadi, kedua benda itu teko dan lemari es sama-sama benda yang berfungsi akan menimbulkan efek dingin pada air yang disimpan pada dua benda itu dalam waktu yang lama. Demikian halnya, kata bahasa Arab Sudan غَاَّاْيَه /ghallaayah/, berarti wajan untuk menggoreng makanan dalam bahasa Amiyah Suriah berarti alat untuk mengaduk kopi. Akar kata [g்alayah] adalah $\boldsymbol{g}(a) \boldsymbol{l}(a) \boldsymbol{y}(a) \boldsymbol{h}$.

Keraf memberi contoh kemiripan fonetis dan semantik yang terjadi secara kebetulan dalam bahasa Indonesia dengan Yunani, misalnya kata mata dalam bahasa Indonesia dan mati dalam bahasa Yunani. Kata badh dalam bahasa Didinga Sudan yang berarti 'jahat' dan kata Inggris bad yang bermakna 'buruk'. Kata man dalam bahasa Korea dan man dalam bahasa Inggris yang bermakna 'orang'.

\section{Pinjaman (Borrowing)}

Keraf menjelaskan bahwa pinjaman merujuk kepada suatu kemiripan bentuk-makna terjadi karena suatu bahasa akseptor menyerap unsur tertentu dari sebuah bahasa donor akibat kontak dalam sejarah (Keraf, 1996, p. 131). Pinjaman bahasa merupakan istilah teknis untuk penggabungan kata dari suatu bahasa ke bahasa lain, baik kata-kata, unsur tata bahasa maupun bunyi-bunyi bahasa untuk berkomunikasi. Pinjaman bahasa ke bahasa lain, dapat berupa kosa-kata, unsur tata bahasa dan bunyi. Umumnya, pinjaman bahasa melibatkan peristiwa adaptasi dari sebuah kata ke dalam sistem fonetik dan tata bahasa dari bahasa lainya, demikian (Mestherie, 2011, p. 214). Berikut kosakata bahasa Arab yang dipinjam oleh bahasa Inggris pada tabel 5.

Tabel 5. Kosakata Bahasa Arab yang dipinjam oleh Bahasa Inggris

\begin{tabular}{|c|c|c|c|c|c|c|}
\hline No. & Makna & $\begin{array}{l}\text { Arabic } \\
\text { word }\end{array}$ & $\begin{array}{l}\text { IPA Pronunciation/ } \\
\text { transliterasi fonetik }\end{array}$ & $\begin{array}{l}\text { English } \\
\text { word }\end{array}$ & $\begin{array}{l}\text { IPA Pronunciation/ } \\
\text { transliterasi fonetik }\end{array}$ & Ihwal Peminjaman terjadi \\
\hline 1. & 'kopi’ & 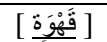 & /qahwah/ & /kahveh/ & /'kpfi/ & Akhir abad ke-16 \\
\hline 2. & 'gula' & 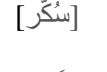 & /sukkar/ & /sugar/ & /'Juga/ & $\begin{array}{l}\text { Abad Pertengahan }(1150 \\
1400)\end{array}$ \\
\hline 3. & 'tembakau' & [ طَبَقق] & /tabaq/ & /tobacco/ & /ta'bakəo/ & Pertengahan abad ke-16 \\
\hline 4. & 'alcohol’ & ] آلَكُحُول & /al-kuhlıl/ & /alcohol/ & /'alkəhpl/ & Pertengahan abad ke-16 \\
\hline 5. & 'zero' & ] [صفر ] & /șifr / & /zero/ & /'ziərəठ/ & Awal abad ke 17 \\
\hline
\end{tabular}

Sumber Data: Oxford English Dictionary (Oxford English Dictionary, 2018)

Tabel 5 menunjukkan gejala peminjaman kosa kata. Setiap masyarakat bahasa yang terbuka akan selalu mengadakan kontak sosial dengan masyarakat bahasa lain. Dampak dari kontak sosial itu adalah peminjaman satuan bahasa berupa kosakata. Peminjaman kosa kata mengakibatkan posisi setiap penutur bahasa belajar kosa kata yang dianggap baru yang berasal dari bahasa tetangga sebelahnya. Contoh kosakata / قََهْوَة / /qahwah/ berarti 'kekuatan' merupakan kata asal bahasa Arab kata ini dikenal dalam bahasa Inggris coffee. Ethiopia merupakan negara tempat tanaman kopi berasal. Tanaman ini tumbuh di dataran tinggi negara itu. Pada mulanya tanaman kopi hanya dikenal oleh masyarakat 
Ethiopia sebagai tanaman liar, namun sering digunakan sebagai makanan. Kosa kata ini mulai dikenal oleh masyarakat luas pada akhir akhir abad ke-16. Kosakata / سَبَاق / / سُكَّكَ /

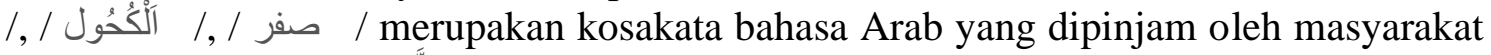
bahasa Inggris. Kata / سئَّك / 'gula' mulai dipinjam oleh Inggris pada abad pertengahan pada rentang tahun 1150-1400, kata / طَبَاق / 'tembakau', diserap masuk ke dalam bahasa Inggris pada abad ke 16. Kata / آَّكُحُول / dipinjam ke dalam bahasa Inggris abad ke-16 (Miller, 2015, pp. 21-25; Oxford English Dictionary, 2018). Berikut kosakata perabot dapur bahasa Sudan dan Suriah yang meminjam dari bahasa lain pada tabel 6 .

Tabel 6. Kosakata Perabot Dapur Bahasa Sudan dan Suriah yang Meminjam dari Bahasa Lain

\begin{tabular}{|c|c|c|c|c|c|c|}
\hline No. & Makna & $\begin{array}{l}\text { Kosakata } \\
\text { Sudan }\end{array}$ & $\begin{array}{l}\text { IPAPronunciation/ } \\
\text { Transliterasi fonetik }\end{array}$ & $\begin{array}{l}\text { Kosakata } \\
\text { Suriah }\end{array}$ & $\begin{array}{l}\text { IPA Pronunciation/ } \\
\text { transliterasi fonetik }\end{array}$ & Keterangan \\
\hline 1. & 'termos' & تَرَمْمُونْن & /tarmuus/ & ترمس شاب & /tirmuss sya'ay/ & $\begin{array}{l}\text { Awal abad ke-20: } \\
\text { dari Latin }\end{array}$ \\
\hline 2. & 'mikrowave' & مَكُرُوْوروبْفِ & /makruuwiif/ & ميكروويف & /miikroowiif/ & Inggris \\
\hline
\end{tabular}

Sumber Data: Oxford English Dictionary(Oxford English Dictionary, 2018)

Data pada table 5 dan 6 menunjukkan adanya gejala peminjaman bahasa dari bahasa lain ke dalam bahasa Arab Sudan maupun Suriah. Keadaan ini menunjukkan bahwa setiap masyarakat bahasa mengalami dinamika social. Penutur jati bahasa Arab Sudan maupun Suriah terbuka untuk menerima kosakata kosakata berasal dari masyarakat bahasa lain dengan cara meminjam (borrowing). Dengan kata lain, kebudayaan suatu masyarakat berubah dapat dilihat melalui peralatan makan, peralatan memasak makanan yang disebut dalam tulisan ini peralatan dapurnya. Kebudayaan berubah masyarakat berubah, kehidupan berubah dan bahasa pun ikut berubah.

\section{Pasangan Memiliki Korespondensi Fonemis}

Pasangan kata yang memiliki korespondensi fonemis merupakan pasangan kata yang memiliki hubungan antara kedua bahasa berdasarkan posisi fonem-fonem dan makna yang sama dari kedua bahasa yang dibandingkan sebagaimana pada tabel 7 .

Tabel 7. Kosakata Perabot Dapur Bahasa Sudan dan Suriah yang Berkorespondensi Fonemis

\begin{tabular}{|c|c|c|c|c|c|}
\hline No. & Makna & Kosakata Sudan & IPA Pronunciation & Kosakata Suriah & IPA Pronunciation \\
\hline 1. & 'kompor' & 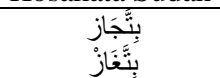 & $\begin{array}{l}\text { /bittajas/ } \\
\text { /bittagas/ }\end{array}$ & راس الغاز & /roos elghaas/ \\
\hline 2. & 'piring' & صَحُحُنْ & /shuhun/ & صحن & /shohen/ \\
\hline 3. & 'sendok' & 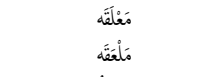 & $\begin{array}{l}\text { /ma'laqah/ } \\
\text { /mal'aqah/ }\end{array}$ & مِلعَاْه & /mileaah/ \\
\hline 4. & $\begin{array}{l}\text { 'pemotong } \\
\text { bawang' }\end{array}$ & فَرَّامْ تُوُْم & /faraam tuum/ & فرّامة توم & /faraamet tuum/ \\
\hline
\end{tabular}

Sumber Gambar: http://www.goethe-verlag.com (Learn English and other languages online for free, n.d.)

Tabel 7 a. Pasangan Kata yang Memiliki Korespondensi Fonemis

\begin{tabular}{|c|c|c|c|c|c|}
\hline Sudan & Pengucapan & Korespondensi terjadi pada & Suriah & Pengucapan & $\begin{array}{l}\text { Korespondensi terjadi } \\
\text { pada }\end{array}$ \\
\hline /shuhun/ & [fuhun] & $\begin{array}{l}/ \int \sim \int /, / \mathrm{u} \sim \mathrm{o} /, / \mathrm{h} \sim \mathrm{h} / \\
/ \mathrm{u} \sim \mathrm{e} /, / \mathrm{h} \sim \mathrm{n} /\end{array}$ & /shohen/ & [ Johen] & $/ \mathrm{u} \sim \mathrm{o} /, \mathrm{lu} \sim \mathrm{e} /$ \\
\hline /mal'aqah/ & [mal'aqah] & $\begin{array}{l}/ \mathrm{m} \sim \mathrm{m} /, / \mathrm{a} \sim \mathrm{i} /, / \mathrm{l} \sim \mathrm{1} /, / \mathrm{P} \sim \mathrm{e} / \\
/ \mathrm{a} \sim \mathrm{a} /, / \mathrm{q} \sim \mathrm{P} /, / \mathrm{a} \sim \mathrm{a} /, / \mathrm{h} \sim \mathrm{h} /\end{array}$ & /milea'ah/ & [milea'ah] & $/ \mathrm{a} \sim \mathrm{i} /, / \mathrm{P} \sim \mathrm{e} /, / \mathrm{q} \sim \mathrm{P}$ \\
\hline /barraad/ & [barraad] & $\begin{array}{l}/ \mathrm{b} \sim \mathrm{b} /, / \mathrm{a} \sim \mathrm{a} /, / \mathrm{r} \sim \mathrm{r} /, / \mathrm{r} \sim \mathrm{r} / \\
/ \mathrm{a} \sim \mathrm{a} /, / \mathrm{a} \sim \mathrm{a} /, / \mathrm{d} \sim \mathrm{d} /\end{array}$ & /barraad/ & [barraad] & \\
\hline
\end{tabular}




\section{Kemiripan secara Fonetis}

Beberapa kosakata peralatan dapur yang memiliki kemiripan secara fonetis karena posisi artikulatoris yang sama, ciri-ciri fonetisnya dapat dianggap sebagai alofon, (Maemunah, 2017, p. 61). Contoh kosakata yang memiliki kemiripan secara fonetis sebagai berikut pada tabel 8 .

Tabel 8. Kosakata Perabot Dapur Bahasa Sudan dan Suriah yang Mempunyai Kemiripan Fonetis

\begin{tabular}{|c|c|c|c|c|c|}
\hline No. & Makna & Kosakata Sudan & $\begin{array}{l}\text { IPA Pronunciation/ } \\
\text { transliterasi fonetik }\end{array}$ & Kosakata Suriah & $\begin{array}{l}\text { IPA Pronunciation/ } \\
\text { transliterasi fonetik }\end{array}$ \\
\hline 1. & 'tutup penggorengan' & غُطَاءْ & /ghuthaal & غطى مئلاية & /ghata milaayeh/ \\
\hline 2. & 'tempat bumbu' & عِلْب بُخَارَاتْ & /'ilb bhukhaaraat/ & علبة بهار ات & lealbet buharaat/ \\
\hline 3. & 'blender' & خَلَّاط & /khallaath/ & خلاط & /khallaat/ \\
\hline 4. & 'baskom' & طَشْتَتْ & /thasyt/ & شُشَطْ & /tusyutt/ \\
\hline
\end{tabular}

Sumber Gambar: http://www.goethe-verlag.com (Learn English and other languages online for free, n.d.)

Untuk mengamati kemiripan secara fonetis antara bahasa Arab Sudan dan Suriah digunakan pendekatan fonetik yaitu suatu disiplin ilmy yang mempelajari bunyi bahasa tanpa mempertimbangkan arti. Fonetik yang dipakai untuk menganalisis data ini yaitu fonetik artikulatoris, (Arifuddin, 2013, p. 146) Fonetik artikulatoris, yaitu membahas cara kerja ucap manusia dalam menghasilkan bunyi. Mulai dari paru-paru, tenggorokan, lidah, bibir atas, bibir bawah dan gigi. Vokal diidentifikasi sebagai bunyi yang bersuara, yang terjadi dengan menggetarkan klep pita suara melalui tekanan, sedangkan dalam pembentukannya, udara yang datang dari paru-paru tidak mendapat hambatan di kerongkongan dan rongga mulut. Dalam bahasa Arab vokal dalam ada tiga yaitu fathah, kasrah, dan dhammah.

Data pada tabel 8, kata yang bermakna cover of skillet 'tutup panci' dalam bahasa Arab Sudan / غُطَاْْ / dilafalkan /ghuthaa/ tidak sama dengan kata dalam bahasa Arab Suriah / غطئ مئلاية / yang dilafalkan /ghata milaayeh/. Ada perubahan bunyi dari bahasa Sudan /u/ atau dhamah menjadi /a/ fathah dalam bahasa Suriah. Hal yang sama juga terjadi pada kata yang bermakna basin atau 'mangkuk' pada bahasa Arab Sudan / /

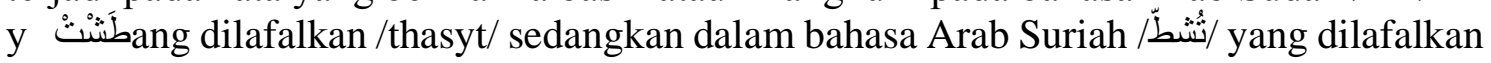
/tusyut/.

\section{Satu atau Beberapa Fonem yang Berbeda}

Satu fonem berbeda bila pasangan kata terdapat perbedaan satu fonem tetapi dapat dijelaskan perbedaan fonem tersebut karena pengaruh lingkungan yang dimasukinya. Dalam bahasa lain, pengaruh lingkungan itu tidak mengubah fonem, maka pasangan itu ditetap pula sebagai kata kerabat, asal segmennya cukup panjang. (Keraf, 1996, p. 128) Contoh kosakata yang memiliki fonem berbeda antara lain pada tabel 9.

Tabel 9. Kosakata Perabot Dapur Bahasa Sudan dan Suriah yang Mempunyai Satu Fonem Berbeda

\begin{tabular}{|c|c|c|c|c|c|}
\hline No. & Makna & $\begin{array}{l}\text { Kosakata } \\
\text { Sudan }\end{array}$ & $\begin{array}{l}\text { IPA Pronunciation/ } \\
\text { Transliterasi Fonetik }\end{array}$ & $\begin{array}{l}\text { Kosakata } \\
\text { Suriah }\end{array}$ & $\begin{array}{l}\text { IPA Pronunciation/ } \\
\text { Transliterasi Fonetik }\end{array}$ \\
\hline 1. & 'dapur' & مَتْبَخْ & /mathbakh/ & مَطَبَخْ & /matbakh/ \\
\hline 2. & 'kompor listrik' & فُرُنْن كَهْرُبَا & /furrun kahrubaal & فرن كهربا & /furrun kahrubaal \\
\hline $\begin{array}{l}3 . \\
4 .\end{array}$ & $\begin{array}{l}\text { 'penggorengan' } \\
\text { 'kompor' }\end{array}$ & كَنَنْجَرَهْ & $\begin{array}{l}\text { /thanjarah/ } \\
\text { /kanuun/ }\end{array}$ & طنجرة بخار & $\begin{array}{l}\text { /tanjaret bukhaar/ } \\
\text { /kaanuun/ }\end{array}$ \\
\hline
\end{tabular}

Sumber Gambar: http://www.goethe-verlag.com (Learn English and other languages online for free, n.d.)

Perbedaan fonem pada tabel 9 di atas adalah perbedaan: a) satu fonem; dan b) beberapa fonem. Perbedaan itu sebagai berikut: /th/ ke /t/; /a/ ke /e/; /h/ ke /t/; /a/ ke /a:/. 
Table 9 menunjukkan ada perubahan bunyi konsonan dari bahasa Arab Sudah ke bahasa Arab Surian pada datum nomor 1. Konsonan hambat / b / merubah menjadi / ت / merujuk kepada adalah bunyi yang ketika diartikalusikan mendapat hambatan kuat dari organ bicara dan tidak terdapat jalan keluar udara, baik dari hidung atau dari samping kiri dan kanan mulut sehingga udara terhambat di belakang organ bicara tersebut. Kemudian organ bicara tersebut membuka jalan udara dengan cepat, yang mengakibatkan terdengarnya bunyi seperti letupan. Konsonan yang terjadi dengan cara artikulasi apikodental dan daerah artikulasi hambat, inilah yang disebut dengan bunyi letupan atau bunyi hambat. Bunyi /th/ dan /t/ merupakan dua bunyi hambat perbedaannya hanya pada pita suara bergetar dan tidak bergetar. Pola serupa juga terjadi pada kata / طَنْجَرَ / dilafalkan dalam bahasa Sudan /thanjarah/ bermakna 'dandang', sedangkan di dalam bahasa Arab Suriah / طنجرة بخار / yang dilafalkan /tanjaret bukhaar/. Pada datum nomor 4

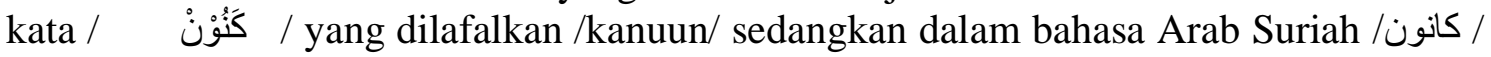
yang dilafalkan /kaanuu/ ada perubahan dari bunyi /a/ pendek dalam bahasa Sudan menjadi /a:/ dalam bahasa Suriah. Perubahan bunyi vokal dalam kosakata peralatan dapur ini sangat banyak pada data penelitian ini, misalnya misalnya dari /a/ pendek menjadi /a:/ Panjang; bunyi /i/ pendek menjadi bunyi /i:/ Panjang; bunyi /u/ pendek menjadi bunyi /u:/ Panjang. Bunyi-bunyi vokal lebih cepat berubah dari satu bahasa ke bahasa lain dibandingkan dengan bunyi konsonan, demikian dikemukakan oleh (Trask, 2010, p. 12; Wardhaugh, 2006, p. 191). Gejala di atas dapat pula dikemukakan bahwa bahasa Sudan dan Suriah meskipun merupakan dua bahasa yang berbeda namun banyak kosakata dalam bidang peralatan dapur terdapat bunyi-bunyi fonetis hampir identik sebagaimana pada tabel 10 .

Tabel 10. Kosakata Peerabot Dapur Bahasa Sudan dan Suriah yang Berbentuk Kata Majemuk

\begin{tabular}{|c|c|c|c|c|c|}
\hline No. & Makna & $\begin{array}{l}\text { Kata Majemuk } \\
\text { Sudan }\end{array}$ & $\begin{array}{l}\text { IPA Pronunciation/ } \\
\text { transliterasi fonetik }\end{array}$ & $\begin{array}{l}\text { Kata Majemuk } \\
\text { Suriah }\end{array}$ & $\begin{array}{l}\text { IPA Pronunciation/ } \\
\text { Transliterasi Fonetik }\end{array}$ \\
\hline 1. & 'keranjang maju' & سَبَّبتنْ زِبَالَه & /sabbat zibaalah/ & سلة زبالة & /sallet zibaaleh/ \\
\hline 2. & 'rak piring' & رَفُ الُْعِدَّه & /rafful 'iddahh/ & مشكّ صحون & /misyakk shehuun \\
\hline 3. & 'kompor listrik' & فُرُُنْ كَهْرُبَا & /furrun kahrubaal & فرن كهربا & /furen kahrabaal \\
\hline 4. & 'taplak meja' & فَرَشْن صُفْرَه & /farasy shufrah/ & شرشف الصفره & /syarsyaf eshshufrah/ \\
\hline 5. & 'alat bakar roti' & سَخَاْنْ إِيْشُْ & $\begin{array}{l}\text { /sakhaan khubz/ } \\
\text { /sakhaan isy/ }\end{array}$ & ش شوّا اية خبز & /syawwayet khubez/ \\
\hline 6. & 'cangkir' & طَقْمُ شَتَاب & /thaqmu syaay/ & كاسة شاي & /kaaset syaay/ \\
\hline 7. & 'tempat bumbu' & عِلْب بُخَارَاتَتْ & /ilb bukhaaraat/ & علبة بهار ات & /'ilbet bahaaraat/ \\
\hline
\end{tabular}

Data pada table 10 diidentifikasi sebagai kata majemuk. Kata majemuk adalah gabungan dua kata atau lebih yang membentuk satu keatuan arti yang mempunyai sifat ketaktersisipan oleh unsur lain, demikian dikemukakan oleh (Keraf, 1980, pp. 123-126); (Andrew \& Zwicky, 2007, pp. 52-53). Uraian data pada table 10 membicarakan bahasa Arab Sudan dan Suriah dari tinjauan ciri arti dan konstruksi morfologis. Ciri arti merujuk kepada seluruh unsur pembentuk kata majemuk itu hanya mengusung satu makna atau arti, misalnya pada datum nomor 1 kata / سَبََتْْ زِبَالَه / / /sabbat zibaalah/ dalam bahasa Sudan dan / سلة زبال / dalam bahasa Suriah hanya mengandung satu arti yaitu 'tempat sampah' salah satu nama perlengkapan alat yang terdapat di dapur. Hal yang sama juga terjadi pada datum nomor 2, kata / رَفَّ الْعِدَّه / dilapaflkan /rafful'iddah/ dalam bahasa Sudan dan / مشكّد صحون / dalam bahasa Suriah menunjukkan satu arti yaitu 'rak tempat menyimpan piring'. Kontruksi kata majemuk pada table 10 secara konstruksi dibangun

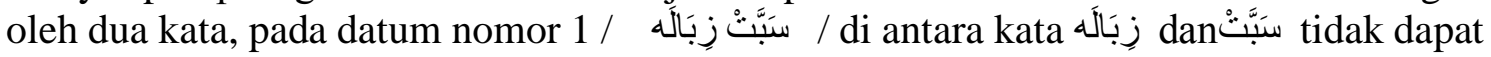
disisipkan kata lain misalnya وَ وَ/. Kontruksi gabungan dua kata atau lebih yang dapat disisipkan suatu bentuk bahasa disebut frase. Menurut (Andrian, 2016, pp. 103-104), 
frasa dalam bahasa Arab dikenal dengan terminologi tarkih, yaitu perpaduan satu bahasa yang saling terpadu dan menempat posisi tertentu dalam kalimat. Misalnya pada kalimat pada tabel 11.

Tabel 1. Konstruksi Frasa

\begin{tabular}{|c|c|c|}
\hline No. & Konstruk Frasa Bahasa Arab & Makna \\
\hline & رَجْلُ صَالِحِح & 'pemuda yang cerdas' \\
\hline & 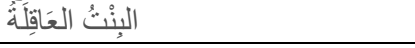 & 'anak perempuan yang cerdas' \\
\hline
\end{tabular}

Penjelasan bentuk frasa pada nomor 1, رَجُلْ dilafalkan rajulun merujuk kepada kata yang disifati atau kata yang dijelaskan dalam bahasa Arab disebut maushuf. Sedangkan, satuan bahasa berupa صَالِحِ jang dilafakan shaalihun merujuk kepada kata menjelaskan

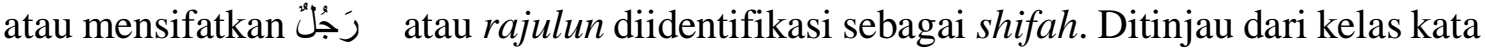
pembentuk frase maka رَجْلَ atau rajulun adalah mufrad atau kata benda bentuk tunggal dan terminoloi shifah berarti sifat dalam bentuk mufrad atau sifat tunggal yaitu shaalih. Khusus untuk frasa dalam bahasa Arab untuk mengidentifikasi jumlah benda ada tiga kategori untuk menentukan jumlah benda, yaitu: mufrad (tunggal), tasniyah (dua), dan jamak (plural/lebih dari dua). Kata benda atau isim mufrad الإنْنُ الَْْْفرَدُ isim yang menunjukkan jumlah satu atau tunggal, misalnya مُسْلِّمَ /muslimun/ yang artinya 'seorang muslim' sُسَِِْْة /muslimatun/ yang bermakna 'seorang muslimah' كَنَابٌ /kitaabun/ 'sebuah buku'.

Penjelasan bentuk frasa pada datum nomor 2, kata النْنُ dilafalkan albintu diiedntifikasi sebagai maushuf. Di sisi lain, kata العَاقَلَة

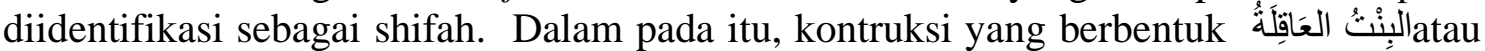
al-bintu ma'rifah, memiliki kata sifat ma'rifah yaitu al-'aaqilah. Konstruksi frase ini menunjukkan susunan frase berbentuk kata sifat dan kata benda. Dalam bahasa Arab Sudan maupun Syiria terdapat rangkaian frasa kata benda. Dalam bahasa itu terdapat fitur tanwin atau nakirah, yang menggunakan tanda alif-lam yang diberi istilah ma'rifah, susunan kata yang terletak pada bagian depan disebut Maushuf atau yang disifati sedangkan kata yang letaknya di belakang disebut shifat. Contoh موقد غاز جيد yang secara harafiah 'kompor gas yang bagus'. Data nomor 1 dan 2 menunjukkan konstruksi frase berbeda dengan konstruksi majemuk dalam bahasa Arab.

\section{KESIMPULAN}

Uraian pada bagian pembahasan dan hasil menunjukkan bahwa bahasa Arab Amiyah Sudan dan Suriah dari ranah peralatan dapur memiliki kekerabatan berasal dari satu induk proto yang sama. Fakta itu ditunjukkan dengan terdapatnya pasangan kata yang identik.

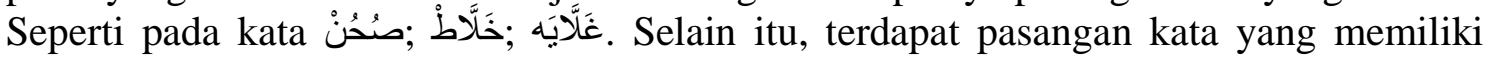
korespondensi fonemis, seperti pada fonem /u o/; /u e/;/a i//; $\sim \mathrm{e} / ; / \mathrm{q} \sim$ ?/. Tambahan pula ada pasangan kosakata yang memiliki kemiripan fonetis, seperti pada kata غطى ; غُطَاء:

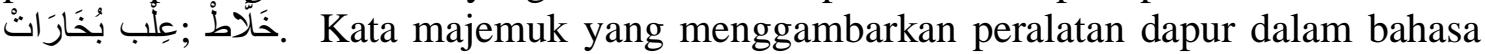
Sudan dan Suriah tidak menunjukkan pasangan kata yang identik atau berkorespondensi secara fonemis, keduanya menunjukkan perbedaan bentuk morfem namun tidak berbeda secara makna. 


\section{REFERENSI}

Andrew, S., \& Zwicky, A. M. (2007). The Handbook of Morphology. Blackwell Publishing. http://www.blckwellreference.com

Andriani, A. (2016). Frase dalam Bahasa Arab (Konstruksi (Frasa Dalam Bahasa Arab Berdasarkan Unsur Pembentuknya). CENDEKIA: Jurnal Studi Keislaman, 2(1), 103-113.

Arifuddin. (2013). Pemikiran-Pemikiran Fonetik Ibnu Jinni (W. 392 H. / 1002 M.). Jurnal CMES Edisi Juli - Desember 2013, Vol.VI, Nomor 2.

Calvani, D. (2003). Initial Overview of the Linguistic Diversity of Refugee Communities in Cairo. Forced Migration and Refugee Studied (FMRS). Working Paper 4. The Amerivan University Cairo, Vol 4, No. 2, 8.

Crowley, T., \& Bowern, C. (2019). An Introduction to Historical Linguistics (First). Oxford University Press.

Djelantik, S. (2016). Terorisme Tinjauan Psiko-Politis, Peran Media, Kemiskinan, dan Keamanan Sosial. Yayayasan Pustaka Obor.

Gazali, E. (2012). Akronim Majemuk dalam Teks Arab Modern. Proceeding International Conference on Applied Linguistics V (CONAPLIN 5): Languge Teacher Development in Globalized World. (2012). p. 147-153. Ed. Wachyu Sundayana. Indonesia University of Education (UPI), 24-25 September 2012. https://www.researchgate.net/publication/312198767

Keraf, G. (1980). Tata Bahasa Indonesia. Nusa Indah.

Keraf, G. (1996). Keraf, Gorys. 1996. Linguistik Bandingan Historis. Jakarta: PT. Gramedia. Gramedia.

La Ino. (2015). Pemanfaatan Linguistik Historis Komparataif Dalam Pemetaan BahasaBahasa Nusantara. RETORIKA: Jurnal Ilmu Bahasa, Vol. 1, No.2, 351-365.

Learn English and other languages online for free. (n.d.). Retrieved February 8, 2020, from http://www.goethe-verlag.com/

Maemunah, E. (2017). "Kekerabatan Bentuk dan Makna Kosakata Peralatan Dapur dalam Bahasa Sunda dan Jawa.” Jurnal Saweragading, Vol. 23, No. 1, 61-69.

Mahmoud, R., \& Rosiny, S. (2015). Opposition Visions For Preserving Syria's EthnicSecterian Mosaic. German Institue of Global Area Studies, p5.

Mahsun, M. S. (2012). Metode Penelitian Bahasa Tahapan Strategi, Meode dan Tekniknya. Rja Grafindo Persada.

Mestherie, R. (2011). Mestherie, Ranjend. (2011). The Cambridge Handbook of: Sociolinguistics. New. Cambridge University Press. 
Miller, R. M. C. (2015). Trask's Historical Linguistics (Second Edition). Routledge. Mu'izzuddin, Moch. (n.d.). Analisis Fonologi Bahasa Arab Tinjauan Linguistik Modern. Al-Qalam, Vol. 19. No 93.

Muysken, P. (2019). Linguistic Dimensions of Language Contact The State of the Art in Interlinguistics. Vol. 14, No. 1. https://doi.org/10.7202/602527aradresse copiéeune erreur s'es

Owen, J. (2015). Arabic language history and the comparative methode. Jounral of Arabic Linguistic, $\quad$ Vol $\quad 1 \quad$ No 1. https://revues.imist.ma/index.php?journal=IJAL\&page=index

Owens, J. (2013). Arabic Dialect History and Historical Linguistic Mythology.Journal of the American Oriental Society. Journal of the American Oriental Society, Vol. 123, No. 4 (Oct.-Dec., 2003), 715-740. https://doi.org/10.2307/3589965

Oxford English Dictionary. (2018). English Dictionary. www.englishoxforddictinary.com

Setiadi, A. C. (2011). "Dialek Bahasa Arab Tinjauan Dialektologis". Jurnal At-Ta'dib, VOl 6, No. 1, 135.

Siemund, P., \& Noemi, K. (2008). Language Contact and Contact Language. Benjamins.

Sudaryanto. (2015). Metode Linguistik: Ke Arah Memahami Metode Linguistik. Gadjah Mada University Press.

Taha, A. T. (2012). "The influence of Dongolawi Nubian on Sudan Arabic". California Linguistics, Vol. 27, No. 2(Spring). http://english.fullerton.edu/publications.pdf

Trask, R. L. (2010). Why Do Languages Change? Cambridge University Press.

Wardhaugh, R. (2006). An Introduction to Sociolinguistics. Blackwell.

World Map: Political. (2008). https://geology.com/world/world-map.shtml

Yule, G. (2010). The Study of Language. Cambridge University Press. 